\title{
PENDEKATAN HIERARKI ABRAHAM MASLOW PADA PRESTASI \\ KERJA KARYAWAN PT. MADUBARU (PG MADUKISMO) YOGYAKARTA
}

\author{
ABRAHAM MASLOW'S HIERARCHICAL APPROACH TO \\ EMPLOYEE PERFORMANCE OF MADUBARU LIMITED COMPANY \\ (PG MADUKISMO) YOGYAKARTA
}

\begin{abstract}
Elisa Sari
Fakultas Ekonomi Jurusan Manajemen Universitas Mercu buana Yogyakarta

Email: elisa.sari@gmail.com

\section{Rina Dwiarti}

Fakultas Ekonomi Jurusan Manajemen Universitas Mercu buana Yogyakarta

Email: rina@mercubuana-yogya.ac.id
\end{abstract}

\begin{abstract}
ABSTRAK
Penelitian ini bertujuan untuk mengetahui pengaruh motivasi berdasarkan hierarki kebutuhan Maslow yang meliputi kebutuhan fisiologis, rasa aman, sosial, penghargaan, dan aktualisasi diri terhadap prestasi kerja karyawan PT. Madubaru (PG Madukismo) Yogyakarta. Teknik pengumpulan data yang digunakan dalam penelitian ini yakni dengan metode wawancara, kuisioner, dokumentasi dan studi kepustakaan yang dilakukan secara sistematik berdasarkan tujuan penelitian. Sampel dalam penelitian ini sejumlah 174 orang yang merupakan karyawan tetap PT. Madubaru (PG Madukismo) Yogyakarta dengan menggunakan teknik proportionate stratified random sampling. Metode analisis yang digunakan yaitu analisis regresi linear berganda, uji parsial ( $u j i$ t), uji simultan (uji F), serta uji adjusted R2 dan determinasi (R2). Hasil penelitian menunjukkan bahwa motivasi berdasarkan hierarki kebutuhan Maslow yang meliputi kebutuhan fisiologis, rasa aman, sosial, penghargaan, dan aktualisasi diri secara simultan mempunyai pengaruh yang signifikan terhadap prestasi kerja karyawan tetap. Sedangkan secara parsial hanya kebutuhan fisiologis dan aktualisasi diri yang signifikan, sedangkan kebutuhan rasa aman, sosial, dan penghargaan secara parsial tidak signifikan. Kebutuhan fisiologis merupakan variabel yang paling dominan mempengaruhi prestasi kerja karyawan tetap PT. Madubaru (PG Madukismo) Yogyakarta.
\end{abstract}

Kata kunci: Motivasi Kebutuhan Abraham Maslow, Prestasi Kerja.

\section{ABSTRACT}

Hal. $58-77$

This study aims to determine the influence of motivation based on Maslow's hierarchy of needs that include physiological needs, sense of security, social, appreciation, and selfactualization to employee performance Madubaru limited company (PG Madukismo) Yogyakarta. Data collection techniques used in this study are interview methods, questionnaires, documentation and literature study conducted systematically based on research objectives. The sample in this study is 174 people who are permanent employees 
of Madubaru limited company (PG Madukismo) Yogyakarta by using proportionate stratified random sampling technique. Method of analysis used are multiple linear regression analysis, partial test ( $t$ test), simultaneous test ( $F$ test), and adjusted test $R 2$ and determination ( $R 2)$. The results showed that motivation based on Maslow's hierarchy of needs that includes physiological needs, sense of security, social, appreciation, and self-actualization simultaneously have a significant effect on the performance of permanent employees. While the partial only physiological needs and self-actualization which is significant, while the need for security, social, and appreciation are partially insignificant. Physiological needs is the most dominant variable affecting the performance of permanent employees of Madubaru limited company (PG Madukismo) Yogyakarta.

\section{Keywords: Abraham Maslow's Motivation Needs, Job Performance.}

\section{PENDAHULUAN}

Perusahaan manufaktur (pabrik atau industri) merupakan perusahaan yang kegiatannya mengolah bahan baku menjadi barang jadi yang kemudian siap dipasarkan. Tantangan yang dihadapi perusahaan manufaktur di era globalisasi ini semakin berat dan persaingan bisnis pun semakin sengit karena selain perkembangan teknologi yang semakin canggih, perusahaan juga dihadapkan dengan perdagangan bebas, dimana barang atau produk apapun bebas keluar

masuk suatu negara tanpa dikenai bea cukai. Perdagangan bebas memberikan dampak yang positif dan negatif. Bagi perusahaan yang sudah memiliki tim manajemen yang kuat yang sudah dipersiapkan sejak lama untuk menghadapi perasaingan global, maka ini akan menjadi peluang emas baginya untuk memperluas pasar. Namun bagi perusahaan yang tidak mempersiapkan manajemennya untuk menghadapi tantangan perdagangan bebas, maka hal ini akan menjadi bencana besar bagi perusahaan tersebut karena tanpa persiapan dan strategi yang matang maka perusahaan tersebut akan dengan mudah tergilas oleh zaman. Era globalisasi merupakan era persaingan sumberdaya manusia (SDM). Maka penting bagi Manager Human Resources Development (HRD) untuk dapat mengelola SDM nya secara efektif, salah satunya dengan memberikan motivasi kepada karyawan dengan memperhatikan apa yang menjadi kebutuhan karyawan itu sendiri. Mengapa demikian? karena tentunya seseorang bekerja tak lain hanya untuk memenuhi kebutuhan mereka, dengan memenuhi apa yang dibutuhkan karyawan maka karyawan tersebut akan memberikan feedback (umpan balik) positif bagi perusahaan yakni mereka akan bekerja dengan semangat dan dengan hati yang senang sehingga kinerja/prestasi kerja karyawan pun meningkat dan rasa nyaman bekerja pun akan menimbulkan loyalitas karyawan.

Manajer HRD dapat mengetahui apa yang menjadi kebutuhan karyawannya dengan berpatokan pada teori motivasi kebutuhan yang banyak dikemukakan oleh para ahli. Salah satu teori motivasi kebutuhan yang merangkum kebutuhan dasar hidup manausia adalah teori motivasi kebutuhan yang dikemukakan oleh Abraham Maslow. Maslow mengklasifikasikan kebutuhan manusia kedalam lima hierarki yang mana pemenuhannya bersifat berjenjang dalam artian ketika kebutuhan dasar itu terpenuhi maka ia akan naik ke kebutuhan selanjutnya hingga mencapai kebutuhan pada tingkat tertinggi. Teori kebutuhan Maslow ini telah menerima pengakuan luas diantara manajer pelaksana karena teori ini logis secara intuitif. Selain itu teori Maslow telah banyak digunakan secara luas dalam dunia industri untuk menunjukkan adanya hubungan antara pekerja dengan performansi kerja Berdasarkan latar belakang di atas, penulis tertarik untuk mengetahui pengaruh motivasi terhadap prestasi kerja karyawan dan faktor kebutuhan apa yang paling dominan memotivasi prestasi kerja karyawannya dengan menggunakan pendekatan teori hierarki kebutuhan Maslow. Pendekatan teori ini pun bisa menciptakan budaya perusahaan 
yang makin baik, terlebih dikaitkan dengan strategi hijau dimasa yang akan datang (Rokhyadi, Haryono, \& Untoro, 2015).

\section{LANDASAN TEORI \\ Prestasi Kerja}

Sedangkan menurut Sunyoto (2013) prestasi kerja merupakan perwujudan seseorang dalam melakukan pekerjaan. Seseorang dapat dikatakan berprestasi, manakala mereka dapat melaksanakan pekerjaan dengan baik, artinya mencapai sasaran dengan standar yang telah ditentukan. (Sunyoto, Danang, 2013: 17)Penilaian prestasi kerja (performance appraisal), menurut Handoko (2014) merupakan proses melalui mana organisasi-organisasi mengevaluasi atau menilai prestasi kerja karyawan. Kegiatan ini dapat memperbaiki keputusan-keputusan personalia dan memberikan umpan balik kepada para karyawan tentang pelaksanaan kerja mereka. (Handoko, T. Hani, 2014: 135). Edwin Flippo (1995) dalam Sunyoto (2013) mengemukakan bahwa prestasi kerja seseorang dapat diukur melalui (Sunyoto, Danang, 2013: 17-18): Mutu kerja, Kualitas kerja, Ketangguhan, Sikap.

Kegunaan penilaian prestasi kerja dapat dirinci sebagai berikut (Handoko, T. Hani, 2014: 135): Perbaikan Prestasi Kerja, Penyesuaian-Penyesuaian Kompensasi, KeputusanKeputusan Penempatan, Kebutuhan-Kebutuhan Pelatihan dan Pengembangan, Perencanaan dan Pengembangan Karier, Penyimpangan-Penyimpangan Proses Staffing, Ketidak-akuratan Informasional, Kesalahan- Kesalahan Desain Pekerjaan, Kesempatan Kerja yang Adil, Tantangan-Tantangan Eksternal.

Faktor-faktor yang mempengaruhi prestasi kerja seseorang menurut Mangkunegara (2009), adalah sebagai berikut:

1. Faktor Kemampuan

Pegawai perlu ditempatkan pada pekerjaan yang sesuai dengan kemampuannya (the right man on the right place, the right man on the right job).

2. Faktor Motivasi

Motivasi terbentuk dari sikap (attitude) seorang pegawai dalam menghadapi situasi (situation) kerja. Sikap mental merupakan kondisi yang mendorong diri pegawai untuk berusaha mencapai prestasi kerja secara maksimal. Sikap mental seorang pegawai harus siap secara psikofisik (siap mental, fisik, tujuan dan situasi). Artinya, seorang pegawai harus mampu secara mental, mampu secara fisik, memahami tujuan utama, dan target kerja yang akan dicapai serta mampu memanfaatkan dan menciptakan situasi kerja. (Purnama, Sejati, 2012: 4, http://eprints.uny.ac.id/ 9622/ 1/ JURNAL.pdf, diakses 11 Oktober 2014, pukul 23.10 WIB)

\section{Motivasi}

Hasibuan (2007) mengartikan motivasi kerja sebagai pemberian daya penggerak yang menciptakan kegairahan kerja seseorang, agar mereka mau bekerjasama, bekerja efektif dan terintegrasi dengan segala daya upayanya untuk mencapai kepuasan. (Hasibuan, $\mathrm{H}$. Malayu S.P., 2007: 95)

Tujuan pemberian motivasi (Sunyoto, Danang, 2013: 10) antara lain: Mendorong gairah dan semangat kerja karyawan, Meningkatkan moral dan kepuasan kerja karyawan, Menigkatkan produktivitas kerja karyawan, Mempertahankan loyalitas dan kesetabilan karyawan perusahaan, Meningkatkan kedisiplinan dan menurunkan tingkat absensi karyawan, Menciptakan suasana dan hubungan kerja yang baik, Meningkatkan kreativitas dan partisipasi karyawan, Meningkatkan kesejahteraan karyawan, Mempertinggi rasa tanggung jawab karyawan terhadap tugas-tugasnya.

Adapun jenis-jenis teori motivasi (Sunyoto, Danang, 2013: 2-7) diantaranya meliputi: 


\section{Teori Motivasi Kepuasan (Content Theory).}

Teori ini mencoba mencari tahu tentang kebutuhan apa yang dapat memuaskan dan yang dapat mendorong semangat kerja seseorang. Semakin tinggi standar kebutuhan dan kepuasan yang diinginkan, maka semakin giat seseorang untuk bekerja. Teori kebutuhan (content theory) ini meliputi Teori Hierarki Kebutuhan Maslow, Teori E-R-G, Teori Dua Faktor dari Frederick Herzberg, dan Teori Motivasi Prestasi/Three Need Theory dari Mc. Clelland.

\section{Teori Motivasi Proses (Process Theory)}

Teori ini berusaha agar setiap karyawan mau bekerja giat sesuai dengan harapan. Daya penggerak yang memotivasi semangat kerja terkandung dari harapan yang akan diperolehnya. Jika harapan menjadi kenyataan maka karyawan cenderung akan meningkatkan kualitas kerjanya, begitu pula sebaliknya. Ada 3 macam teori motivasi proses yang utama menurut Husein Umar (1998) dalam Sunyoto (2013) yakni meliputi Teori Penghargaan (Expectancy Theory), Teori Keadilan, dan Teori Penguatan.

Dari sekian jenis teori motivasi diatas, teori motivasi yang digunakan penulis dalam penelitian ini adalah teori motivasi yang dikembangkan oleh Abraham Maslow yang dikenal dengan "Teori Hierarki Kebutuhan". Alasan penulis menggunakan teori ini, karena teori ini merupakan teori dasar yang mewakili kebutuhan-kebutuhan manusia. Dalam hierarki kebutuhan Maslow, kita dapat melihat dimana posisi karyawan tersebut berada, sehingga nantinya dapat diberikan bentuk motivasi yang tepat untuk masing-masing karyawan.

\section{Teori Hierarki Kebutuhan Maslow}

Maslow's Need Hierarchy Theory atau A Theory of Human Motivation, dikemukakan oleh Abraham Maslow tahun 1943 menyatakan bahwa kebutuhan dan kepuasan seseorang itu jamak yaitu meliputi kebutuhan biologis dan psikologis berupa materiil dan non materiil. (Hasibuan, H. Malayu S.P., 2007: 104). Dalam teori kebutuhan Maslow, ketika kebutuhan dasar sudah terpenuhi maka kebutuhan berikutnya menjadi dominan. Dari sudut motivasi, teori tersebut mengatakan bahwa meskipun tidak ada kebutuhan yang benar-benar dipenuhi, sebuah kebutuhan yang pada dasarnya telah dipenuhi tidak lagi memotivasi. (Robbins dan Timoty, 2009: 224).

Hierarki kebutuhan manusia menurut Maslow adalah sebagai berikut (Sunyoto, Danang, 2013: 2-3):

1. Kebutuhan fisiologis (phisiological needs)

Kebutuhan fisiologis merupakan hierarki kebutuhan manusia yang paling dasar yang merupakan kebutuhan untuk dapat hidup meliputi sandang, pangan, papan seperti makan, minum, perumahan, tidur, dan lain sebagainya.

2. Kebutuhan rasa aman (safety needs)

Kebutuhan akan rasa aman ini meliputi keamanan secara fisik dan psikologis. Keamanan dalam arti fisik mencakup keamanan di tempat pekerjaan dan keamanan dari dan ke tempat pekerjaan. Kemanan fisik ini seperti keamanan dan perlindungan dari bahaya kecelakaan kerja dengan memberikan asuransi dan penerapan prosedur K3 (Keselamatan dan Kesehatan Kerja), serta penyediaan transportasi bagi karyawan. Sedangkan keamanan yang bersifat psikologis juga penting mendapat perhatian. Keamanan dari segi psikologis ini seperti perlakuan yang manusiawi dan adil, jaminan akan kelangsungan pekerjaannya, jaminan akan hari tuanya pada saat mereka tidak ada lagi, dls. (Siagian, Sondang P., 2012: 150-151)

3. Kebutuhan sosial (social needs)

Meliputi kebutuhan untuk persahabatan, afiliasi (hubungan antar pribadi yang ramah dan akrab), dan interaksi yang lebih erat dengan orang lain. Dalam organisasi akan 
berkaitan dengan kebutuhan akan adanya kelompok kerja yang kompak, supervisi yang baik, rekreasi bersama.

4. Kebutuhan penghargaan (esteem needs)

Kebutuhan ini meliputi kebutuhan dan keinginan untuk dihormati, dihargai atas prestasi seseorang, pengakuan atas faktor kemampuan dan keahlian seseorang serta efektivitas kerja seseorang. (Sunyoto, Danang, 2013: 3) Maslow membagi kebutuhan akan rasa harga diri/penghargaan ke dalam dua sub, yakni penghormatan dari diri sendiri dan penghargaan dari orang lain. Sub pertama mencakup hasrat dari individu untuk memperoleh kompetensi, rasa percaya diri, kekuatan pribadi, adekuasi, prestasi, kemandirian, dan kebebasan. Kesemuanya mengimplikasikan bahwa individu ingin dan perlu mengetahui bahawa dirinya mampu menyelesaikan segenap tugas atau tantangan dalam hidupnya. Sub yang kedua mencakup antara lain prestasi. Dalam hal ini individu butuh penghargaan atas apa-apa

yang dilakukannya. Penghargaan ini dapat berupa pujian, pengakuan, piagam, tanda jasa, hadiah, kompensasi, insentif, prestise (wibawa), status, reputasi, dls. (Koeswara, E., 1995: 228-229)

5. Kebutuhan aktualisasi diri (self actualization needs)

Aktualisasi diri merupakan hierarki kebutuhan dari Maslow yang paling tinggi. Aktualiasasi diri berkaitan dengan proses pengembangan akan potensi yang sesungguhnya dari seseorang. (Sunyoto, Danang, 2013: 3). Pemenuhan kebutuhan ini dapat dilakukan oleh para pimpinan perusahaan dengan menyelenggarakan pendidikan dan pelatihan, memberikan otonomi untuk berkreasi, memberikan pekerjaan yang menantang, dan lain sebagainya.

\section{Revisi Teori Maslow}

Hierarki kebutuhan Maslow telah mengalami revisi yaitu pada tahun 1970 dan 1971. Pada tahun 1970, Maslow memisahkan kecenderungan tingkah laku yang ada dalam aktualisasi diri menjadi kebutuhan kognitif dan kebutuhan estetika. Tahun 1791 Maslow menemukan beberapa orang bisa mengaktualisasikan dirinya melalui kemampuan diri dan pengalaman sendiri. Oleh Maslow, kemampuan seperti itu disebut sebagai kemampuan akan transendensi. Akan tetapi Maslow tidak pernah memasukkan self transcendence ke dalam hierarki kebutuhannya. Tapi peneliti penerus Maslow seperti Henry Gleitman Alan Fridlund, dan Daniel Reisberg mamasukkannya sebagai hierarki paling tinggi yaitu hierarki kedelapan. Menurut versi yang paling baru, hierarki kebutuhan manusia terdiri dari delapan level, yaitu: kebutuhan fisiologis, kebutuhan akan rasa aman, kebutuhan $\mathrm{s}$ osial, kebutuhan penghargaan, kebutuhan kognitif, kebutuhan estetika, kebutuhan aktualisasi diri, dan kebutuhan transendensi. (Nisa, Valina Khiarin, 2014, "Sejarah Psikologi Humanistik", Blogger Unair, Universitas Airlangga, valinanisa327-fpsi11.web.unair.ac.id/artikel_detail-93076Umum- Sejarah \% 20 Psikologi \% 20 Humanistik.html, diakses pada tanggal 16 November 2014 pukul 20.45 WIB).

\section{Kebaikan dan Kelemahan Teori Hierarki Kebutuhan Maslow}

Teori hierarki kebutuhan Maslow ini mempunyai kebaikan dan kelemahan sebagai berikut (Hasibuan, Malayu, S. P., 2007: 107):

Kebaikannya:

1. Teori ini memberikan informasi bahwa kebutuhan manusia itu jamak (materiil dan nonateriil) dan bobotnya bertingkat-tingkat pula.

2. Manajer mengetahui seseorang berperilaku/bekerja adalah untuk dapat memenuhi kebutuhan-kebutuhan (materiil dan non-materiil) yang akan memberikan kepuasan baginya. 
3. Kebutuhan manusia itu berjenjang sesuai dengan kedudukan atau sosial ekonominya. Seseorang yang berkedudukan rendah (sosial ekonominya lemah) cenderung dimotivasi oleh materiil, sedang orang yang berkedudukan tinggi cenderung dimotivasi oleh nonmateriil.

4. Manajer akan lebih mudah memberikan alat motivasi yang paling sesuai untuk merangsang semangat bekerja bawahannya.

Kelemahannya:

1. Menurut teori ini kebutuhan manusia itu adalah bertingkat-tingkat atau hierarki, tetapi dalam kenyataannya manusia menginginkannya tercapai sekaligus dan kebutuhan manusia itu merupakan siklus, seperti lapar-makan-lapar lagi makan lagi dan seterusnya.

2. Walaupun teori ini sangat populer, tetapi belum pernah dicoba kebenarannya, karena Maslow mengembangkannya hanya atas dasar pengamatan saja.

Hofstede (dalam Stoner dan Freeman, 1994, dalam buku Edy Sutrisno, 2010), mampu menentukan sejauh mana teori Maslow dapat diterapkan di negara-negara lain untuk membantu manajemen memotivasi karyawannya. Ia menemukan terdapat banyak perbedaan diantara berbagai kebudayaan dan juga perbedaan dalam motivasi karyawan, gaya manajemen. Hofstede menyimpulkan bahwa teori motivasi seperti hierarki kebutuhan dari Maslow sama sekali bukan gambaran dari proses motivasi manusia universal. Sebaliknya, bahwa itu merupakan gambaran dari sistem nilai, yakni sistem nilai masyarakat kelas menengah Amerika Serikat yang mana Maslow masuk di dalamnya.

Negara-negara yang mengembangkan sistem nilai lain bisa jadi menganggap kebutuhan akan rasa aman melampaui kebutuhan sosial atau penghargaan diri. Contoh, di Swedia, yang cukup berhasil menerapkan gaya manajemen partisipatif, kebutuhan sosial bernilai lebih dari kebutuhan akan penghargaan. Di Jerman, Jepang, Swiss, Italia, dan Austria, kebutuhan akan rasa aman pada umumnya dinilai lebih daripada kebutuhan akan penghargaan. Di Kanada, India, dan Inggris seperti juga di Amerika Serikat, pada umumnya prinsip teori Maslow diterapkan relatif baik (Sutrisno, Edy, 2010: 127-128).

Bagaimanapun juga teori kebutuhan Maslow juga telah menerima pengakuan luas diantara anajer pelaksana karena teori ini logis secara intuitif. Namun, penelitian tidak memperkuat eori ini dan Maslow tidak memberikan bukti empiris dan beberapa penelitian yang berusaha engesahakan teori ini tidak menemukan pendukung yang kuat. (id.m.wikepedia.org/wiki/ Motivasi, diakses tanggal 3 November 2014 pukul 20.19 WIB). Terlepas dari itu semua, teori Maslow telah banyak digunakan secara luas dalam dunia industri untuk menunjukkan adanya hubungan antara pekerja dengan performansi kerja (Robert, Thomas B., 1972).

\section{Pengaruh Motivasi Kebutuhan Terhadap Prestasi Kerja}

Dilihat dari segi prestasi kerja, orang yang berada di dalam organisasi dapat dikelompokkan menjadi dua macam, yaitu mereka yang mampu berprestasi lebih baik daripada yang lain dan mereka yang kurang berprestasi. Prestasi dari masing-masing individu dipengaruhi oleh beberapa faktor. Beberapa variabel penting yang berpengaruh terhadap prestasi kerja adalah faktor kebutuhan, fakor usaha dan kemampuan, faktor lingkungan kerja dan faktor kepemimpinan.

Kebutuhan atau needs dapat dipandang sebagai pembangkit dan penggerak perilaku. Ini berarti bahwa apabila terdapat kekurangan akan kebutuhan, maka orang akan lebih peka terhadap motivasi. Dengan demikian, kebutuhan berhubungan erat dengan $\mathrm{k}$ ekurangan yang dialami oleh seseorang. Kekurangan itu dapat bersifat fisiologis (makanan, pakaian, dan tempat tinggal), psikologis (pengakuan atau penghargaan) dan sosial (berkelompok). Apabila berbagai macam kebutuhan itu dapat terpenuhi atau berbagai macam kekurangan itu dapat diatasi, maka akan memberikan dorongan kepada seseorang untuk berprestasi lebih baik, oleh karena itu motivasi utama seseorang masuk menjadi anggota suatu 
organisasi (menjadi manusia organisasi) adalah untuk memenuhi berbagai macam kebutuhan tersebut. (Wursanto, Ig., 2005: 299-300)

\section{HIPOTESIS}

a. Diduga bahwa terdapat pengaruh yang signifikan antara motivasi kebutuhan Maslow yang meliputi kebutuhan fisiologis, rasa aman, sosial, penghargaan, dan aktualisasi diri secara simultan terhadap prestasi kerja karyawan PT. Madubaru (PG Madukismo) Yogyakarta.

b. Diduga bahwa terdapat pengaruh yang signifikan antara motivasi kebutuhan Maslow yang meliputi kebutuhan fisiologis, rasa aman, sosial, penghargaan, dan aktualisasi diri secara parsial terhadap prestasi kerja karyawan PT. Madubaru (PG Madukismo) Yogyakarta.

c. Diduga bahwa variabel yang paling dominan mempengaruhi prestasi kerja karyawan adalah kebutuhan akan aktualisasi diri.

\section{METODE PENELITIAN}

\section{Lokasi Penelitian}

Lokasi penelitian dilakukan di PT. Madubaru (PG Madukismo), yang beralamat di Desa Padokan, Kelurahan Tirtonirmolo, Kecamatan Kasihan, Kabupaten Bantul, Propinsi Daerah Istimewa Yogyakarta.

\section{Populasi dan Sampel Penelitian}

Populasi dalam penelitian ini adalah karyawan tetap PT. Madubaru (PG Madukismo), dengan kategori karyawan bagian pelaksanan yang berjumlah 308 orang pada tahun 2014.

Penentuan jumlah sampel menggunakan rumus Slovin dengan alpha $5 \%$ diperoleh jumlah sampel sebanyak 174 orang.

\section{Metode Sampling yang Ditempuh}

Menggunakan metode proportionate stratified random sampling, yakni merupakan teknik yang hampir sama dengan simple random sampling namun penentuan sampelnya memeperhatikan strata (tingkatan) yang ada dalam populasi. Dengan demikian, setelah diketahui jumlah sampel dari populasi dengan tingkat kesalahan 5\%, jumlah tersebut akan didistribusikan ke dalam masing-masing divisi yang ada di dalam perusahaan dengan menggunakan rumus sebagai berikut (Noor, Juliansyah, 2013: 152)

$$
\mathrm{n}=\underset{\text { jumlah populasi keseluruhan }}{\mathrm{populasi} \text { kelas }} \quad \mathrm{x} \text { jumlah sampel yang ditentukan }
$$

Kuesioner untuk variabel $\mathrm{X}$ akan didistribusikan kepada karyawan tetap bagian pelaksana yang berada di setiap devisi, dengan jumlah kuesioner di setiap devisi disesuaikan dengan perhitungan jumlah sampel dari tiap devisi seperti yang terlihat di atas, sedangkan kuesioner untuk variabel $Y$ akan didistribusikan kepada pimpinan tiap-tiap devisi dengan jumlah 10 orang. Butir pernyataan kuesioner didasarkan pada penelitian Agus Sulaiman (2011) dari Universitas ITB dan didasarkan buku Danang Sunyoto (2013) yang berjudul "Perilaku Organisasional: Teori, Kuesioner, \& Proses Analisis Data". 


\section{Variabel Penelitian dan Pengukuran}

Variabel Bebas $(X)$ merupakan variabel yang mempengaruhi atau yang menjadi sebab perubahan (Noor, Juliansyah, 2013: 49). Variabel bebas dalam penelitian ini adalah motivasi kebutuhan menurut Maslow yang terdiri dari kebutuhan fisiologis (X1), kebutuhan rasa aman (X2), kebutuhan sosial (X3), kebutuhan penghargaan (X4) dan kebutuhan aktualisasi diri (X5). Variabel terikat atau dependent variable Variabel Terikat (Y) atau dependent variable merupakan variabel yang dijelaskan atau dipengaruhi oleh variabel bebas. Variabel terikat dalam penelitian ini adalah prestasi kerja karyawan. Variabel terikat dalam penelitian ini adalah prestasi kerja karyawan.

Penilaian kuesioner untuk variabel bebas dan terikat menggunakan skala likert (Noor, Juliansyah, 2013: 128) dengan bobot penilaian sebagai berikut:

$\begin{array}{ll}\text { Sangat Tidak Setuju (STS) } & =1 \\ \text { Tidak Setuju (TS) } & =2 \\ \text { Netral (N) } & =3 \\ \text { Setuju (S) } & =4 \\ \text { Sangat Setuju (SS) } & =5\end{array}$

\section{Sumber Data yang Diperlukan}

1. Data Primer adalah data yang diperoleh berdasarkan pengukuran secara langsung oleh peneliti dari sumbernya: kuesioner dan wawancara secara langsung

2. Data Sekunder adalah data yang diperoleh secara tidak langsung: dokumen-dokumen perusahaan dan buku-buku literature.

\section{Teknik Pengumpulan Data}

1. Metode Wawancara, merupakan salah satu teknik pengumpulan data yang dilakukan dengan berhadapan secara langsung dengan yang diwawancarai tetapi dapat juga diberikan daftar pertanyaan dahulu untuk dijawab pada kesemapatan lain. (Noor, Juliansyah, 2013: 138)

2. Metode Kuesioner/Angket, merupakan cara mengumpulkan data primer dengan menggunakan seperangkat daftar pertanyaan mengenai variabel yang diukur melalui perencanaan yang matang, disusun dan dikemas sedemikian rupa, sehingga jawaban dari semua pertanyaan benar-benar dapat menggambarkan keadaan variabel yang sebenarnya (Mustafa, Zainal, 2009: 99).

3. Metode Dokumentasi, merupakan kegiatan mencari data atau variabel dari sumber berupa catatan, transkrip, buku, surat kabar, majalah, prasasti, notulen rapat, agenda, dan sebagainya (Saryono, 2011: 81). Studi dokumentasi dilakukan dengan menelaah catatan tertulis, dokumen, dan arsip tersebut yang menyangkut masalah yang diteliti, berhubungan dengan instansi terkait.

4. Metode Studi Pustaka, merupakan metode yang dilakukan dengan mempelajari bukuuku dan refrensi yang berhubungan langsung dengan pengaruh motivasi kebutuhan menurut Maslow terhadap prestasi kerja karyawan.

\section{METODE ANALISIS DATA}

1. Analisis kualitatif merupakan suatu analisis terhadap data dengan melakukan pengelompokan berdasarkan karakteristik tertentu ke dalam tabel (Sunyoto, Danang, 2013: 148). Karakteristik responden dalam penelitian ini adalah jenis kelamin, jenjang pendidikan, usia, dan lama bekerja.

2. Analisis Kuantitatif merupakan suatu analisis yang menggunakan angka-angka untuk menguji hepotesis mengenai pengaruh dan hubungan motivasi berdasarkan kebutuhan menurut Abraham Maslow terhadap prestasi kerja karyawan PT. Madubaru (PG Madukismo) Yogyakarta. 
a. Uji Validitas (uji kesahihan instrument) digunakan untuk mengukur seberapa tepat instrument itu mampu menghasilkan data sesuai dengan ukuran yang sesungguhnya yang ingin diukur (Mustafa, Zainal, 2009: 164). Untuk mengetahui kelayakan butirbutir pertanyaan dalam kuesioner dalam mendefinisikan suatu variabel, maka perlu diuji dengan uji analisis correlation matrix anti-image dan KMO and Bartlett's test of sphericity. Butir kuesioner dikatakan valid apabila nilai anti-image correlation tiap butir pertanyaan $>0,70$.

b. Uji Reliabilitas, digunakan untuk menilai kestabilan ukuran dan konsistensi responden dalam menjawab kuesioner. Uji reliabilitas dilakukan dengan cara uji analisis correlation matrix anti-image dan KMO and Bartlett's test of sphericity. Butir pertanyaan dikatakan reliabel atau handal apabila nilai kaiser-meyer-olkin measure of sampling adequacy $>0,70$.

c. Pengujian Asumsi Klasik

Tujuan pengujian asumsi klasik ini adalah untuk memberikan kepastian bahwa persamaan regresi yang didapatkan memiliki ketepatan dalam estimasi, tidak bias dan konsisten. Adapun asumsi klasik yang digunakan adalah:

1) Uji Normalitas

Persamaan regresi dikatakan baik jika mempunyai data variabel bebas dan data variabel terikat berdistribusi normal atau mendekati normal. Pengujian distribusi normal dilakukan dengan menggunakan normal probability plot, data dikatakan berdistribusi normal jika garis data riil mengikuti garis diagonal (Sunyoto, Danang, 2010: 108). Serta dilakukan pengujian secara statistik dengan menggunkan kolmogorov-smirnov one sampel test, dengan kriteria pengujian: jika nilai sig. (signifikansi) $>0,05$ maka data berdistribusi normal, sedangkan jika nilai sig. (signifikansi) $<0,05$ maka data tidak berditribusi normal.

2) Uji Linearitas

Uji linearitas dilakukan untuk menguji linear tidaknya data yang dianalisis. Persamaan regresi yang baik adalah regresi yang mempunyai hubungan yang linear antar variabelnya. Cara yang dilakukan untuk menguji liniearitas regresi dilakukan dengan menggunkan aplikasi SPSS, yakni dengan fungsi "Compare Means". Interprestasinya adalah: jika nilai $\mathrm{F}$ hitung < Ftabel maka hubungan antara $\mathrm{X}$ dengan $Y$ adalah linear. Jika $F$ hitung $>$ Ftabel maka hubungan antara variabel independent $(X)$ dengan variabel dependen $(Y)$ adalah tidak linear.

3) Uji Multikolinieritas

Pengujian ini digunakan untuk mengetahui apakah antar variabel bebas dalam persamaan regresi tersebut saling berkorelasi atau tidak. Persyaratan yang harus dipenuhi dalam model regresi adalah tidak boleh ada multikolinearitas.

Metode yang digunakan untuk mendeteksi adanya multikolinieritas adalah:

i. Melihat besaran koefisien korelasi $(r)$

Terjadi multikolinieritas, jika $r>0,60$,

Tidak terjadi multikolinearitas jika $r<0,60$.

ii. Menggunakan nilai tolerance dan Value Inflation Faktor (VIF)

Nilai tolerance (a) dan VIF dapat dicari dengan menggabungkan kedua nilai tersebut sebagai berikut:

Besar nilai tolerance (a): $a=1 /$ VIF

Besar nilai VIF: VIF $=1 / \mathrm{a}$

Dengan kriteria penilaian, variabel bebas mengalami multikolinieritas jika: a hitung < a dan VIF hitung > VIF. (Sunyoto, Danang, 2010: 97)

d) Uji Heteroskedastisitas

Dalam persamaan regresi berganda perlu juga diuji mengenai sama atau tidak varians dari residual dari observasi yang satu dengan observasi yang lain. Jika 
residualnya mempunyai varians yang sama disebut terjadi Homoskedastisitas dan jika variansnya tidak sama/berbeda disebut terjadi Heteroskedastisitas.

Persamaan regresi yang baik jika tidak terjadi Heteroskedastisitas.Pengujian ini dilihat dari hasil output SPSS melalui grafik scatterplot antara Z prediction (ZPRED) yang merupakan variabel bebas (sumbu X) dan nilai residualnya (SRESID) merupakan variabel terikat (sumbu Y). Homoskedastisitas terjadi jika pada scatterplot titik-titik hasil pengolahan data antara ZPRED dan SRESID menyebar di bawah maupun di atas titik orgin (angka 0 ) pada sumbu $Y$ dan tidak mempunyai pola yang teratur. Heteroskedastisitas terjadi jika pada scatterplot titik-titiknya mempunyai pola yang teratur baik menyempit, melebar maupun bergelombanggelombang. (Sunyoto, Danang, 2010: 100-101)

\section{ANALISIS REGRESI LINEAR BERGANDA}

Digunakan untuk mengetahui ada tidaknya pengaruh signifikan dua atau lebih variabel bebas $(X 1, X 2, X 3, X 4, X 5)$ terhadap variabel terikat $(Y)$. Rumus regresi linear berganda adalah sebagai berikut (Sunyoto, Danang, 2011: 61):

$\mathrm{Y}=\mathrm{a}+\mathrm{b} 1 \mathrm{X} 1+\mathrm{b} 2 \mathrm{X} 2+\mathrm{b} 3 \mathrm{X} 3+\ldots . .+\mathrm{bn} \mathrm{Xn}$

Dalam penelitian ini menggunakan lima variabel bebas atau lima prediktor sehingga rumusnya menjadi sebagai berikut:

$\mathrm{Y}=\mathrm{a}+\mathrm{b} 1 \mathrm{X} 1+\mathrm{b} 2 \mathrm{X} 2+\mathrm{b} 3 \mathrm{X} 3+\mathrm{b} 4 \mathrm{X} 4+\mathrm{b} 5 \mathrm{X} 5$

Keterangan:

$\mathrm{Y}=$ Variabel terikat (prestasi kerja)

$\mathrm{a}=$ Bilangan konstanta

$\mathrm{b} 1, \mathrm{~b} 2, \ldots ., \mathrm{b} 5=$ Koefisien regresi prediktor $\mathrm{X} 1, \mathrm{X} 2, \ldots . ., \mathrm{X} 5$

$\mathrm{X} 1=$ Variabel bebas kebutuhan fisiologis

$\mathrm{X} 2=$ Variabel bebas kebutuhan rasa aman

$\mathrm{X} 3=$ Variabel bebas kebutuhan sosial

X4 = Variabel bebas kebutuhan penghargaan

X5 = Variabel bebas kebutuhan aktualisasi diri

\section{Uji Simultan (Uji F)}

Uji ini digunakan untuk mengetahui pengaruh bersama-sama variabel bebas terhadap varibel terikat. Dimana Fhitung > Ftabel, maka Ho ditolak atau secara bersama-sama variabel bebas dapat menerangkan variabel terikatnya secara serentak. Sebaliknya apabila Fhitung< Ftabel, maka Ho diterima atau secara bersama-sama variabel bebas tidak memiliki pengaruh terhadap variabel terikat. $\mathrm{F}$ tabel diperoleh dengan menggunakan alpha (a) $=5 \%$, dengan (df) pembilang (numerator) dan df penyebut (denominator) $=(5 ; 168)$, diperoleh dari rumus $\mathrm{df}=(\mathrm{m} ; \mathrm{n}-\mathrm{m}-1)=(5 ; 174-5-1)=(5 ; 168)$, maka diperoleh nilai $F$ tabel sebesar 2,27 . Keterangan: $n$ adalah jumlah sampel dan $m$ adalah jumlah variabel bebas.

\section{Uji Parsial (Uji t)}

Uji ini dimaksudkan untuk mengetahui apakah ada pengaruh yang nyata dari masing-masing variabel bebas $\mathrm{X} 1, \mathrm{X} 2, \mathrm{X} 3, \mathrm{X} 4, \mathrm{X} 5$ terhadap variabel terikat prestasi kerja (Y). Jika t hitung berada di antara - ttabel dan $+\mathrm{t}$ tabel maka Ho diterima (berarti koefisien regresi tidak signifikan pada taraf nyata). Jika t hitung $>+$ ttabel atau $\mathrm{t}$ hitung $<-$ ttabel maka Ho ditolak. Hal ini berarti koefisien regresi signifikan pada taraf nyata. Tingkat signifikan (a) yang digunakan dalam penelitian ini adalah $5 \%$ atau 0,05 , sedangkan besarnya nilai df dicari dengan rumus (df) $=\mathrm{n}-2=174-2=172$, dengan menggunakan pengujian dua sisi maka nilai t tabel terletak pada $(a / 2 ; d f)=(0,05 / 2 ; 172)=(0,025 ; 172)$ sehingga diperoleh nilai t tabel $=1,97385=1,974$. Keterangan: $\mathrm{n}$ adalah jumlah sampel. 


\section{Definisi Operasional Variabel}

1. Variabel independen/variabel bebas $(X)$ dalam penelitian ini adalah motivasi. Motivasi yang digunkan dalam penelitian ini dalah jenis motivasi kepuasan yang dikemukaan oleh Abraham Maslow dimana teorinya dikenal sebagai Teori Hierarki Kebutuhan Abraham Maslow. Variabel tersebut meliputi:

a. Kebutuhan Fisiologis (X1), meliputi perasaan setiap berangkat kerja, tunjangan perumahan, waktu istirahat, jam kerja, dorongan dari keluarga, kemampuan karyawan untuk menghidupi keluarganya dari bekerja, sistem penggajian, tunjangan makan, dan tunjangan bahan pokok.

b. Kebutuhan Rasa Aman (X2), meliputi fasilitas kesehatan, tunjangan kesehatan, hubungan kerja, kesejahteraan pegawai, kesesuaian gaji dengan beban kerja, sistem pengembangan karir, penerapan prosedur K3 (Keselamatan dan Kesehatan Kerja), sistem penilaian kinerja, hak-hak karyawan, upah lembur, suasana kerja, tunjangan pensiun, pemberian THR (Tunjangan Hari Raya), sistem bonus, ketepatan pembayaran gaji, dan tunjangan transportasi.

c. Kebutuhan Sosial (X3), meliputi motivasi dari atasan, rasa saling membantu, kesempatan bersosialisasi dengan rekan kerja, rasa saling menghargai, tingkat perasaan karyawan dalam bekerja dengan rekan kerjanya, serta interaksi karyawan dengan rekan kerja di luar perusahaan.

d. Kebutuhan Penghargaan (X4), meliputi penghargaan atas prestasi, pemberian pujian, bentuk penghargaan, pengaruh jabatan terhadap status sosial, kebijaksanaan pimpinan, gaya kepemimpinan, dan pengaruh status karyawan perusahaan terhadap status sosial karyawan.

e. Kebutuhan Akutualisasi Diri (X5), meliputi pemberian otonomi untuk berkreasi; kesesuaian pekerjaan dengan keterampilan yang dimiliki; motivasi internal untuk terus bekerja keras dan meningkatkan prestasi; pribadi yang bersemangat dan menyukai hal-hal baru; pekerjaan yang menantang; ketepatan waktu penyelesaian pekerjaan; kebutuhan akan peningkatan keterampilan, potensi diri dan karir; serta tingkat perasaan karyawan terhadap program peningkatan keterampilan dan potensi diri.

2. Variabel dependen $(\mathrm{Y})$ adalah prestasi kerja, merupakan hasil kerja yang ditunjukan oleh seorang karyawan. Indikatornya meliputi:

a. Mutu kerja, meliputi tingkat kecermatan dan kesalahan pegawai, ketepatan waktu dalam meyelesaikan pekerjaan, hasil kerja yang memenuhi standar, serta menunjukkan hasil kerja sebaik mungkin.

b. Kualitas kerja, meliputi kesediaan untuk lembur, dan bersedia melakukan pekerjaan lain yang bukan tugasnya dalam situasi mendesak.

c. Sikap, meliputi kemampuan untuk bekerjasama dengan rekan kerja, tidak menundaunda pekerjaan, keseriusan dalam menyelesaikan tugas, dan tidak membuang waktu kerja dengan kegiatan lain di luar tugas.

d. Inisiatif, meliputi kesediaan karyawan dalam melaksananakan pekerjaan tanpa diperintah atasan, serta bersedia memperbaiki kesalahan tanpa diperintah atasan.

\section{HASIL DAN PEMBAHASAN}

1. Analisis Kualitatif

a. Jenis Kelamin

Berdasarkan hasil kuesioner dapat diketahui mayoritas responden berjenis kelamin laki-laki engan jumlah 155 orang atau $89 \%$, sedangkan responden perempuan hanya berjumlah 19 orang atau $11 \%$ dari total sampel 174 orang.

b. Usia

Berdasarkan hasil kuesioner diketahui bahwa mayoritas responden dalam penelitian ini berusia diatas atau sama dengan 46 tahun dengan jumlah 81 orang atau $46 \%$. 
c. Jenjang Pendidikan

Berdasarkan hasil kuesioner dapat diketahui jenjang pendidikan responden dalam enelitian ini mayoritas adalah SMA dengan jumlah 124 orang atau $71 \%$.

d. Masa Kerja

Berdasarkan hasil kuesioner dapat diketahui masa kerja mayoritas responden lebih dari 8 tahun dengan jumlah 127 orang atau $73 \%$.

2. Analisis dan Pembahasan Deskriptif Mengenai Motivasi dan Prestasi Kerja Karyawan

a. Motivasi Kerja Berdasarkan Kebutuhan Fisiologis

Faktor motivasi tertinggi keseluruhan pegawai berdasarkan kebutuhan fisiologis adalah emberian waktu istirahat yang ideal. Namun berdasarkan metode mean diketahui jika perusahaan ingin memberikan sistem penggajian yang memenuhi kebutuhan hidup layak lagi karyawannya maka perusahaan terlebih dahulu meciptakan suasana kerja yang nyaman ehingga karyawan selalu merasa senang setiap kali berangkat kerja.

b. Motivasi Kerja Berdasarkan Kebutuhan Rasa Aman

Faktor motivasi tertinggi keseluruhan pegawai berdasarkan kebutuhan rasa aman adalah suasana kerja yang nyaman. Namun berdasarkan metode mean diketahui jika perusahaan ingin menetapkan sistem pengembangan karir yang lebih baik maka perusahaan terlebih dahulu memenuhi pembayaran gaji yang sesuai (sesuai dalam artian disini adalah besarnya gaji yang diberikan sesuai UMR \{Upah Minimum Regional\} maupun waktu pembayaran gaji yang sesuai dengan waktu yang ditetapkan).

c. Motivasi Kerja Berdasarkan Kebutuhan Sosial

Faktor motivasi tertinggi keseluruhan pegawai berdasarkan kebutuhan sosial adalah rasa solidaritas antar sesama karyawan yakni saling tolong menolong jika ada teman kerja yang mengalami kesulitan dalam menyelesaikan pekerjaannya. Namun berdasarkan metode mean diketahui jika karyawan ingin dihargai di perusahaan selayaknya ada interaksi sosial yang baik antar sesama rekan kerja maupun dengan atasan.

d. Motivasi Kerja Berdasarkan Kebutuhan Penghargaan

Faktor motivasi tertinggi keseluruhan pegawai berdasarkan kebutuhan penghargaan adalah kebijakasanan pimpinan dalam menghadapi pegawai. Namun berdasarkan metode mean diketahui jika karyawan ingin memperoleh jabatan yang baik di perusahaan maka karyawan terlebih dahulu menunjukkan prestasi kerjanya, sehingga dengan prestasi kerja yang ditunjukkan karyawan dari waktu ke waktu semakin baik maka perusahaan akan memberikan penghargaan bagi karyawan tersebut dengan memberikan feedback (umpan balik) berupa kenaikan jabatan.

e. Motivasi Kerja Berdasarkan Kebutuhan Aktualisasi Diri

Faktor motivasi tertinggi keseluruhan pegawai berdasarkan kebutuhan aktualisasi diri adalah pekerjaan yang dikerjakan sesuai dengan kompetensi/kemampuan yang dimiliki karyawan. Namun berdasarkan metode mean diketahui jika karyawan ingin diberikan keleluasaan dalam menjalankan wewenang maka karyawan perlu menunjukkan kerja kerasnya walaupun tidak dalam pengawasan, agar mendapatkan kepercayaan dari pimpinan. Dengan sikap gigih yang ditunjukkan dalam bekerja, maka pimpinan akan memberikan kepercayaannya kepada karyawan tersebut, dengan memberikan otoritas untuk melaksanakan pekerjaannya sesuai dengan caranya sendiri.

f. Prestasi Kerja Karyawan

Berdasarkan hasil analisis mean diketahui jika perusahaan ingin meningkatkan prestasi kerja karyawan, maka selain karyawan harus cermat dan tidak melakukan kesalahan dalam melaksanakan tugas serta tidak membuang-buang waktu kerjanya 
dengan kegiatan diluar tugas maka karyawan juga harus bersedia bekerja melewati

batas waktu normal (lembur) jika pekerjaannya belum selesai.

3. Analisis Kuantitatif

Hasil uji validitas dan reliabilitas motivasi kepuasan berdasarkan teori kebutuhan Maslow memperlihatkan 48 item pernyataan yang diuji cobakan, dimana 9 item untuk kebutuhan fisiologis, 16 item untuk kebutuhan rasa aman, 6 item untuk kebutuhan sosial, 7 item untuk kebutuhan penghargaan, dan 10 item untuk kebutuhan aktualisasi diri, menghasilkan 43 item valid dan 5 item tidak valid yakni F5, F8, F9, RA12 dan RA16. Sedangkan untuk prestasi kerja memperlihatkan semua item pernyataan yang diajukan kepada pimpinan yang berjumlah 12 item semuanya valid dan reliabel. Setelah menghilangkan butir pernyataan yang tidak valid mengenai motivasi maka hasil uji validitas dari butir pernyataan variabel $\mathrm{X} 1-5$ dan $\mathrm{Y}$ dikatakan valid dan reliabel karena menunjukkan nilai lebih besar dar 0,70.

\section{ANALISIS REGRESI BERGANDA}

Diperoleh persamaan regresi berganda lima prediktor sebagai berikut:

$Y=41,697-0,842 X 1+0,094 X 2+0,062 X 3-0,032 X 4+0,423 \times 5$

Sig: $(0,000) \quad(0,001)(0,512) \quad(0,821)(0,899) \quad(0,012)$

Dimana:

Y : Prestasi Kerja

$\mathrm{X} 1$ : Kebutuhan Fisiologis

X2: Kebutuhan Rasa Aman

X3: Kebutuhan Sosial

X4: Kebutuhan Penghargaan

X5: Kebutuhan Aktualisasi Diri

\section{Uji Simultan (Uji F)}

Diperoleh Fhitung sebesar 3,271 > F tabel $(2,27)$ dengan derajad kesalahan $5 \%$ atau taraf keyakinan 95\%, menunjukkan variabel motivasi kebutuhan menurut Maslow yang meliputi kebutuhan fisiologis, rasa aman, sosial, penghargaan, dan aktuaalisasi diri mempunyai pengaruh yang signifikan (berarti) terhadap prestasi kerja karyawan PT. Madubaru (PG Madukismo) Yogyakarta. Hal ini diperkuat dengan hasil signifikansi $F$ hitung sebesar 0,008 < a $(0,05)$ yang menunjukkan bahwa nilai $\mathrm{F}$ hitung signifikan,sehingga dapat diberlakukan ke populasi.

\section{Uji Parsial (Uji t)}

Tabel 1 Hasil Uji t Hitung

\begin{tabular}{lllll}
\hline Variabel & t hitung & Sig. & t tabel & Status \\
\hline Konstanta & 8,389 & 0,000 & 1,974 & Signifikan \\
X1 & $-3,319$ & 0,001 & 1,974 & Signifikan \\
X2 & 0,658 & 0,512 & 1,974 & Tidak Signifikan \\
X3 & 0,226 & 0,821 & 1,974 & Tidak Signifikan \\
X4 & $-0,127$ & 0,899 & 1,974 & Tidak Signifikan \\
X5 & 2,535 & 0,012 & 1,974 & Signifikan \\
\hline
\end{tabular}

Sumber: Data primer diolah, 2014

Perhatikan nilai Sig hasil uji T pada tabel Coefficients diatas, didapatkan:

1. Kebutuhan fisiologis diperoleh nilai thitung $=-3,319<\mathrm{t}$ tabel $=-1,974$, menunjukkan pengaruh variabel kebutuhan fisiologis (X1) terhadap prestasi kerja karyawan PT. Madubaru (PG Madukismo) Yogyakarta signifikan. 
2. Kebutuhan rasa aman diperoleh nilai thitung $=0,658$ berada diantara t tabel $(-1,974$ dan $+1,974)$, menunjukkan pengaruh variabel kebutuhan rasa aman $(X 2)$ terhadap prestasi kerja karyawan PT. Madubaru (PG Madukismo) Yogyakarta tidak signifikan.

3. Kebutuhan sosial diperoleh nilai thitung $=0,226$ berada diantara t tabel $(-1,974$ dan + 1,974), menunjukkan pengaruh variabel kebutuhan sosial (X3) terhadap prestasi kerja karyawan PT. Madubaru (PG Madukismo) Yogyakarta tidak ignifikan.

4. Kebutuhan penghargaan diperoleh nilai thitung $=-0,127$ berada diantara $t$ tabel $(-1,974$ dan $+1,974)$, menunjukkan pengaruh variabel kebutuhan penghargaan (X4) terhadap prestasi kerja karyawan PT. Madubaru (PG Madukismo) Yogyakarta tidak signifikan.

5. Kebutuhan aktualisasi diri diperoleh nilai thitung $=2,535>$ ttabel $=1,974$, menunjukkan pengaruh variabel kebutuhan aktualisasi diri (X5) terhadap prestasi kerja karyawan PT. Madubaru (PG Madukismo) Yogyakarta signifikan.

\section{Uji Adjusted R Square dan Determinasi}

1. Adjusted R2=0,062 atau 6,2 \% menunjukkan perubahan prestasi kerja karyawan dapat dijelaskan melalui motivasi kebutuhan Maslow yang meliputi kebutuhan fisiologis, rasa aman, sosial, penghargaan, dan aktualisasi diri sebesar $6,2 \%$.

2. Nilai determinasi $(R 2)=0,089$ atau $D=8,9 \%$ menunjukkan besarnya pengaruh variabel bebas (X1-X5) terhadap variabel terikat $(\mathrm{Y})$ adalah sebesar 8,9\%. Jadi perubahan prestasi kerja karyawan dapat dijelaskan melalui motivasi kebutuhan Maslow yang meliputi kebutuhan fisiologis, rasa aman, sosial, penghargaan, dan aktualisasi diri sebesar $8,9 \%$ sedangkan sisanya $91,1 \%$ dijelaskan oleh variabel bebas lainnya.

\section{Motivasi Kerja Berdasarkan Kebutuhan Fisiologis (X1)}

1. Berdasarkan metode mean untuk kebutuhan fisiologis diketahui jika perusahaan ingin memberikan sistem penggajian yang memenuhi kebutuhan hidup layak bagi karyawannya maka perusahaan terlebih dahulu menciptakan suasana kerja yang nyaman sehingga karyawan selalu merasa senang setiap kali berangkat kerja.

Karyawan yang bekerja dengan perasaan yang senang tentu ia akan bersemangat dalam melakukan pekerjaannya, sehingga prestasi kerja meningkat dan produktivitas pun meningkat. Jika produktivitas meningkat maka profit yang diperoleh perusahaan akan meningkat dan perusahaan dapat memberikan sistem penggajian yang memenuhi kebutuhan hidup layak bagi karyawannya.

2. Berdasarkan hasil analisis regresi secara parsial pada variabel kebutuhan fisiologis diperoleh nilai thitung-3,319 < ttabel1,974, maka variabel kebutuhan fisiologis berpengaruh negatif yang signifikan terhadap prestasi kerja karyawan. Artinya berbagai pernyataan yang termasuk kedalam variabel kebutuhan fisiologis berpengaruh negatif dan penting untuk diperhatikan dan dipenuhi untuk meningkatkan prestasi kerja karyawan. Kebutuhan fisiologis secara parsial signifikan karena kebutuhan ini pemenuhannya dapat dilakukan secara bertahap, artinya karyawan tetap, merasa pemenuhan fisiologis harus dipenuhi terlebih dahulu, baru setelah kebutuhan fisiologis dipenuhi maka pemenuhan kebutuhan akan aktualisasi diri baru muncul. Kebutuhan fisiologis ini masih menjadi salah satu kebutuhan yang memotivasi prestasi kerja karyawan, hal ini sesuai dengan kondisi ekonomi masyarakat Indonesia setelah kebijakan pemerintah mengenai kenaikan harga bahan bakar minyak (BBM), yang secara tidak langsung berdampak pada kenaikan harga sandang, pangan, dan papan sedangkan kenaikan ini tidak diimbangi dengan kenaikan daya beli masyarakatnya. Dengan demikian mungkin hal tersebutlah yang menjadi penyebab mengapa nilai regresi kebutuhan fisiologis negatif. Dalam teori Maslow seharusnya ketika kebutuhan karyawan meningkat maka prestasi kerja karyawan pun meningkat, karena dengan meningkatnya kebutuhan fisiologis hal itu mendorong karyawan untuk bekerja lebih giat, namun yang terjadi disini 
semakin bertambahnya kebutuhan fisiologis karyawan maka prestasi kerja karyawan mengalami penurunan, sebaliknya semakin berkurang atau terpenuhinya kebutuhan fisiologis karyawan maka prestasi kerja karyawan meningkat. Maksudnya ialah pada awalnya dengan gaji yang diperoleh, kebutuhan fisiologis karyawan yang meliputi kebutuhan untuk berpakaian layak (sandang), makan dan minum (pangan), tempat tinggal (papan), tabungan sudah terpenuhi dengan baik, namun apabila kebutuhan fisiologisnya dinaikkan misalnya tadinya pengeluaran untuk membeli beras, minyak goreng, gula, dan kebutuhan dasar rumah tangga lainya tadinya hanya mengeluarkan Rp 300.000,- setelah harga BBM naik pengeluarannya meningkat menjadi Rp 500.000,- , sehingga yang terjadi pendapatan yang diperoleh pun akan berkurang banyak untuk memenuhi kebutuhan fisiologis, yang dampaknya karyawan merasa gaji yang diperoleh sekarang tidak mencukupi kebutuhan fisiologisnya dan ketika tidak ada kenaikan pendapatan, sedangkan pengeluaran untuk kebutuhannya semakin meningkat akan berimbas pada penurunan prestasi kerja karyawan.

3. Berdasarkan nilai regresi untuk kebutuhan fisiologis adalah $-0,842$, menunjukkan besarnya pengaruh kebutuhan fisiologis terhadap prestasi kerja sangat rendah. Sebagaimana dalam landasan teori yang menyatakan bahwa "Dalam teori Maslow, ketika kebutuhan dasar sudah terpenuhi maka kebutuhan berikutnya menjadi dominan. Dari sudut motivasi, teori tersebut mengatakan bahwa meskipun tidak ada kebutuhan yang benar-benar dipenuhi, sebuah kebutuhan yang pada dasarnya telah dipenuhi tidak lagi memotivasi (Robbins dan Timoty, 2009: 224)" maka dalam hal ini kebutuhan fisiologis masih tetap memotivasi prestasi kerja karyawan tetap PT. Madubaru (PG Madukismo) Yogyakarta, namun kadarnya sangat rendah.

\section{Motivasi Kerja Berdasarkan Kebutuhan Rasa Aman (X2)}

1. Berdasarkan metode mean untuk kebutuhan rasa aman diketahui jika perusahaan ingin menetapkan sistem pengembangan karir yang lebih baik maka perusahaan terlebih dahulu memenuhi pembayaran gaji yang sesuai (sesuai dalam artian disini adalah besarnya gaji yang diberikan sesuai UMR \{Upah Minimum Regional\} maupun waktu pembayaran gaji yang sesuai dengan waktu yang ditetapkan). Dengan perusahaan memenuhi pembayaran gaji yang sesuai dengan UMR maka prestasi kerja karyawan akan meningkat, ketika prestasi kerja karyawan meningkat maka perusahaan dapat memberikan penilaian secara objektif mengenai karyawannya yang layak untuk memperoleh pengembangan karir, sehingga penempatan karyawan pun akan tepat (the right man and the right place) dan produktivitas perusahaan pun dapat meningkat.

2. Berdasarkan hasil analisis regresi secara parsial pada variabel kebutuhan rasa aman diperoleh nilai t hitung 0,658 berada diantara $+1,974$, maka variabel kebutuhan rasa aman memiliki pengaruh yang positif namun tidak signifikan terhadap prestasi kerja. Artinya berbagai pernyataan yang termasuk kedalam variabel kebutuhan rasa aman secara individu tidak cukup mempengaruhi motivasi karyawan dalam usaha meningkatkan prestasi kerja. Secara parsial kebutuhan rasa aman tidak signifikan karena mungkin kebutuhan akan rasa aman di PT. Madubaru (PG Madukismo) Yogyakarta sudah sesuai dengan yang diinginkan karyawan tetap sehingga secara individu kebutuhan rasa aman ini tidak lagi mempengaruhi motivasi karyawan dalam meningkatkan prestasi kerja. Terpenuhinya kebutuhan rasa aman ini ditunjukkan dengan hasil kuesioner mengenai pemenuhan kebutuhan rasa aman, yang mana mayoritas responden setuju dengan pernyataan positif yang diajukan.

\section{Motivasi Kerja Berdasarkan Kebutuhan Sosial (X3)}

1. Berdasarkan metode mean untuk kebutuhan sosial diketahui jika karyawan ingin dihargai di perusahaan selayaknya ada interaksi sosial yang baik antar sesama rekan 
kerja maupun dengan atasan. Interaksi sosial yang baik antar sesama karyawan akan menciptakan hubungan kerja yang baik, akrab, dan saling membantu atau tolongmenolong dalam kesulitan, sehingga timbul rasa saling menghargai dan menghormati antar sesama rekan kerja.

2. Berdasarkan hasil analisis regresi secara parsial pada variabel kebutuhan social diperoleh nilai t hitung 0,226 berada diantara $+1,974$, maka variabel kebutuhan sosial memiliki pengaruh yang positif namun tidak signifikan terhadap prestasi kerja. Artinya berbagai pernyataan yang termasuk kedalam variabel kebutuhan sosial tidak cukup mempengaruhi motivasi karyawan dalam usaha meningkatkan prestasi kerja. Secara parsial kebutuhan sosial tidak signifikan karena pemenuhan kebutuhan sosial di PT. Madubaru (PG Madukismo) Yogyakarta sudah sesuai dengan yang diinginkan karyawan tetap sehingga secara individu kebutuhan sosial ini tidak lagi mempengaruhi motivasi karyawan dalam meningkatkan prestasi kerja. Terpenuhinya kebutuhan sosial ini ditunjukkan dari hasil kuesioner mengenai pemenuhan kebutuhan sosial, yang mana mayoritas responden setuju dengan pernyataan positif yang diajukan. Selain itu, terpenuhinya kebutuhan sosial ini tercermin dari rasa nasionalisme yang dijunjung tinggi perusahaan, sehingga tercipta hubungan antar karyawan yang bagaikan keluarga.

\section{Motivasi Kerja Berdasarkan Kebutuhan Penghargaan (X4)}

1. Berdasarkan metode mean untuk kebutuhan penghargaan diketahui jika karyawan ingin memperoleh jabatan yang baik di perusahaan maka karyawan terlebih dahulu menunjukkan prestasi kerjanya, sehingga dengan prestasi kerja yang ditunjukkan karyawan dari waktu ke waktu semakin baik maka perusahaan akan memberikan penghargaan bagi karyawan tersebut dengan memberikan feedback (umpan balik) berupa kenaikan jabatan.

2. Berdasarkan hasil analisis regresi secara parsial pada variabel kebutuhan penghargaan diperoleh nilai t hitung-0,127 berada diantara $+1,974$, maka variabel kebutuhan penghargaan memiliki pengaruh yang negatif dan tidak signifikan terhadap prestasi kerja. Artinya berbagai pernyataan yang termasuk kedalam variabel kebutuhan penghargaan tidak cukup mempengaruhi motivasi karyawan dalam usaha meningkatkan prestasi kerja. Secara parsial kebutuhan penghargaan tidak signifikan karena mungkin pemenuhan kebutuhan penghargaan di PT. Madubaru (PG Madukismo) Yogyakarta sudah sesuai dengan yang diinginkan karyawan tetap sehingga secara individu kebutuhan penghargaan ini tidak lagi mempengaruhi motivasi karyawan dalam meningkatkan prestasi kerja.

3. Namun dari hasil pengujian secara simultan diketahui kebutuhan fisiologis, rasa aman, sosial, penghargaan dan aktualisasi diri memiliki pengaruh yang signifikan terhadap prestasi kerja karyawan. Hal ini menunjukkan bahwa untuk kebutuhan rasa aman, sosial dan penghargaan pemenuhannya tidak bisa dilakukan secara berjenjang atau setahap demi setahap melainkan secara bersamaan, saat karyawan menginginkan kebutuhan fisiologisnya terpenuhi mereka juga menginginkan rasa aman dalam bekerja, hubungan sosial yang baik dengan rekan kerja maupun atasan dan memperoleh penghargaan atas prestasi kerja yang dicapai. Karyawan tetap PT. Madubaru (PG Madukismo) tidak dapat menunggu kebutuhan fisiologis terpenuhi terlebih dahulu baru naik ke kebutuhan selanjutnya rasa aman, kemudian kebutuhan sosial dan penghargaan melainkan pemenuhannya harus secara bersamaan.

\section{Motivasi Kerja Berdasarkan Kebutuhan Aktualisasi Diri (X5)}

1. Berdasarkan metode mean untuk kebutuhan sosial diketahui jika karyawan ingin diberikan keleluasaan dalam menjalankan wewenang maka karyawan perlu menunjukkan kerja kerasnya walaupun tidak dalam pengawasan, agar mendapatkan kepercayaan dari 
pimpinan. Dengan sikap gigih yang ditunjukkan dalam bekerja, maka pimpinan akan memberikan kepercayaannya kepada karyawan tersebut, dengan memberikan otoritas untuk melaksanakan pekerjaannya sesuai dengan caranya sendiri.

2. Hasil analisis regresi secara parsial pada variabel kebutuhan aktualisasi diri diperoleh nilai thitung2,535 > ttabel1,974, maka variabel kebutuhan aktualisasi diri berpengaruh positif yang signifikan terhadap prestasi kerja karyawan. Artinya berbagai pernyataan yang termasuk kedalam variabel kebutuhan aktualisasi diri berpengaruh positif dan penting untuk diperhatikan dan dipenuhi untuk meningkatkan prestasi kerja karyawan. Kebutuhan aktualisasi diri secara parsial signifikan karena kebutuhan aktualisasi diri pemenuhannya dapat dilakukan secara bertahap atau berjenjang sesuai teori hierarki Maslow, artinya karyawan tetap, merasa pemenuhan kebutuhan aktualisasi diri ini akan muncul setelah pemenuhan fisiologis terpenuhi bersamaan dengan kebutuhan rasa aman, sosial, dan penghargaan. Jadi dalam penelitian ini hanya kebutuhan fisiologis dan aktualisasi diri saja yang signifikan secara individu terhadap prestasi kerja, karena pemenuhan kedua kebutuhan ini menurut karyawan dapat dilakukan secara berjenjang atau hierarki. Selain dari segi pemenuhannya, alasan lain mengapa kebutuhan aktualisasi diri signifikan dan memiliki pengaruh yang paling dominan terhadap prestasi kerja adalah dikarenakan mayoritas respondennya sudah memiliki masa kerja lebih dari 8 tahun, sehingga empat kebutuhan sebelum aktualisasi diri yang meliputi kebutuhan fisiologis, rasa aman, sosial dan penghargaan sudah terpenuhi dengan baik di perusahaan ini, hal ditunjukkan dengan hasil kuesioner yang mayoritas responden memberikan jawaban setuju pada pernyataan positif mengenai pemenuhan akan kebutuhan fisiologis, rasa aman, sosial, dan penghargaan. Sehingga untuk sekarang yang paling memicu motivasi karyawan untuk meningkatkan prestasi kerjanya adalah kebutuhan untuk mengembangkan potensi dan keahlian yang dimiliki.

3. Nilai regresi yang positif pada kebutuhan aktualisasi diri ini menunjukkan bahwa semakin tinggi pemenuhan kebutuhan aktualisasi diri maka prestasi kerja karyawan semakin meningkat, sebaliknya penurunan pemenuhan kebutuhan aktualisasi diri akan menurunkan prestasi kerja karyawan.

4. Kebutuhan aktualisasi diri tersebut terwujud dengan cara pemberian wewenang kepada pegawai untuk membuat keputusan sendiri dalam melaksanakan pekerjaannya; pekerjaan dikerjakan memberikan kesempatan untuk menunjukkan kemampuan yang dimiliki; pemberian promosi atau pengembangan karir untuk pegawai yang selalu berusaha untuk meningkatkan prestasi kerjanya; memiliki pribadi yang selalu termotivasi dengan hal-hal baru; pemberian tanggung jawab pekerjaan yang lebih besar dari yang dikerjakan pegawai saat ini; karyawan selalu bekerja keras walaupun tidak ada pengawasan; karyawan mampu meyelesaikan pekerjaannya dengan tepat waktu; peningkatan keterampilan, pengembangan diri, dan karir pegawai yang terjamin di perusahaan, pekerjaan yang ditekuni sesuai dengan bakat dan keterampilan yang dimiliki pegawai; serta adanya program peningkatan keterampilan dan pengembangan potensi diri yang memuaskan dari perusahaan.

5. Karyawan tetap PT. Madubaru (PG Madukismo) Yogyakarta sudah mencapai kebutuhan aktualisasi diri dan kebutuhan ini yang paling dominan. Ketika suatu perusahaan memiliki karyawan yang tingkat kebutuhannya sudah mencapai tingkat aktualisasi diri maka selamat perusahaan tersebut sudah mendapatkan loyalitas dari pegawai tersebut dan mereka akan dengan senang hati memberikan totalitasnya untuk perusahaan. Di era globalisasi yang merupakan era persaingan sumberdaya manusia (SDM), maka perusahaan sangat memerlukan SDM yang tingkat motivasinya sudah mencapai tingkat aktualisasi diri dan PT. Madubaru (PG Madukismo) sudah memilikinya. Loyalitas pegawai terhadap perusahaan ini sudah ditunjukkan dengan masa kerja reponden di PT. Madubaru (PG Madukismo) Yogyakarta yang mayoritas sudah mencapai lebih dari 8 
tahun dengan prosentase $73 \%$. Mengapa karyawan bisa begitu loyal terhadap perusahaan? Jika ditelaah hal ini dikarenakan prinsip atau budaya organisasi yang dibangun oleh perusahaan terpatri dengan baik diantara pegawainya, yakni perusahaan menanamkan rasa Nasionalisme yang tinggi dalam menjalankan roda bisnis perusahaan. Nasionalisme pada hakekatnya adalah untuk kepentingan dan kesejahteraan bersama, sehingga segala kebijakan perusahaan mengenai karyawan selalu mempertimbangkan kesejahteraan pegawainya dan hubungan yang terjalin antar karyawan adalah bagaikan keluarga, perusahan juga mengupayakan agar tidak sampai terjadi PHK (Pemutusan Hubungan Kerja) karyawan. Loyalitas karyawan yang dikarenakan perusahaan sangat memperhatikan kesejahteraan karyawannya ini, terlihat dari program jaminan sosial yang diberikan perusahaan untuk karyawan tetap. Selain itu loyalitas ini juga disebabkan sistem pengupahan karyawan tetap diatur tersendiri oleh Serikat Pekerja dan Direksi, sehingga gaji yang diterima karyawan dapat sesuai dengan keinginan karyawan maupun manajemen.Secara keseluruhan penerapan teori kebutuhan Maslow jika diterapkan di PT. Madubaru (PG Madukismo) Yogyakarta akan tampak sebagai berikut: Nilai adjusted R2 yang rendah yakni 6,2\%, menunjukkan kekuatan Maslow masih belum merata untuk diterapkan di PT. Madubaru (PG Madukismo) Yogyakarta. Hal ini ditunjukkan dengan hasil uji t untuk kebutuhan rasa aman, sosial, dan penghargaan yang tidak signifikan. Sedangkan besarnya pengaruh motivasi berdasarkan kebutuhan Maslow terhadap prestasi Kebutuhan Akatualisasi Diri Kebutuhan FisiologisKebutuhan rasa aman, sosial dan penghargaan kerja karyawan secara bersama-sama tergolong rendah yakni 8,9\% dilihat dari hasil uji koefisien determinasi (R2).Berdasarkan hasil pembahasan di atas maka dapat ditarik suatu kesimpulan bahwa dalam rangka meningkatkan prestasi kerja karyawan tetap bagian pelaksana, sebaiknya perusahaan tetap memperhatikan kebutuhan fisiologis karyawan dan meningkatkan pemenuhan kebutuhan aktualisasi diri, supaya motivasi kerja karyawan meningkat, dan prestasi kerja karyawan pun semakin meningkat.

\section{KESIMPULAN}

Berdasarkan hasil perhitungan dan analisis data di atas dapat disimpulkan sebagai berikut:

1. Hipotesis pertama menyatakan bahwa terdapat pengaruh yang signifikan antara motivasi kebutuhan Maslow yang meliputi kebutuhan fisiologis, rasa aman, sosial, penghargaan, dan aktualisasi diri secara simultan terhadap prestasi kerja karyawan PT. Madubaru (PG Madukismo) Yogyakarta adalah terbukti.

2. Hipotesis kedua menyatakan bahwa terdapat pengaruh yang signifikan antara motivasi kebutuhan Maslow yang meliputi kebutuhan fisiologis dan aktualisasi diri secara parsial terhadap prestasi kerja karyawan PT. Madubaru (PG Madukismo) Yogyakarta adalah terbukti. Sedangkan untuk kebutuhan rasa aman, sosial, dan penghargaan secara parsial tidak terbukti memiliki pengaruh yang signifikan terhadap prestasi kerja karyawan.

3. Hipotesis ketiga menyatakan bahwa variabel bebas yang paling dominan mempengaruhi prestasi kerja karyawan adalah kebutuhan akan aktualisasi diri adalah terbukti.

\section{SARAN}

Berdasarkan hasil analisis data dan hasil kesimpulan di atas, dapat disarankan sebagai berikut:

1. Jika perusahaan ingin menetapkan sistem pengembangan karir yang lebih baik maka sebaiknya perusahaan terlebih dahulu memenuhi pembayaran gaji yang sesuai dengan UMR (Upah Minimum Regional). Dengan perusahaan memenuhi pembayaran gaji yang sesuai dengan UMR maka prestasi kerja karyawan akan meningkat, ketika prestasi kerja karyawan meningkat maka perusahaan dapat memberikan penilaian secara objektif mengenai karyawannya yang layak untuk memperoleh pengembangan karir, sehingga 
penempatan karyawan pun akan tepat (the right man on the right place) dan produktivitas perusahaan pun dapat meningkat.

2. Jika karyawan ingin dihargai di perusahaan selayaknya ada interaksi sosial yang baik antar sesama rekan kerja maupun dengan atasan. Interaksi sosial yang baik antar sesama karyawan akan meciptakan hubungan kerja yang baik, akrab, dan saling membantu atau tolong-menolong dalam kesulitan, sehingga timbul rasa saling menghargai dan menghormati antar sesama rekan kerja.

3. Jika karyawan ingin memperoleh jabatan yang baik diperusahaan maka sebaiknya karyawan terlebih dahulu menunjukkan prestasi kerjanya, sehingga dengan prestasi kerja yang ditunjukkan karyawan dari waktu ke waktu semakin baik, maka perusahaan akan memberikan penghargaan bagi karyawan tersebut dengan memberikan feedback(umpan balik) berupa kenaikan jabatan.

4. Sebaiknya perusahaan memperhatikan kebutuhan fisiologis dan kebutuhan aktualisasi diri karyawan, dalam meningkatkan prestasi kerja karyawan.

\section{DAFTAR PUSTAKA}

Handoko, T. Hani, 2014, "Manajemen Personalia dan Sumberdaya Manusia", Edisi Ke-2, Cetakan ke-21, BPFE, Yogyakarta., 135

Hasibuan, H. Malayu S. P., 2007, "Organisasi dan Motivasi: Dasar Peningkatan Produktivitas", Cetakan ke-5, PT. Bumi Aksara, Jakarta., 95, 104, 107 id.m.wikepedia.org/wiki/Motivasi, diakses tanggal 3 November 2014 pukul 20.19 WIB.

Koeswara, E., 1995, "Motivasi: Teori dan Penelitiannya", Cetakan ke (angka terakhir),Angkasa, Bandung., 228-229

Mustafa, Zainal, 2009, "Mengurai Variabel Hingga Instrumentasi", Edisi Pertama, Cetakan Pertama, Graha Ilmu, Yogyakarta., 99, 164

Nisa, Valina Khiarin, 2014, "Sejarah Psikologi Humanistik", Blogger Unair, Universitas Airlangga, valinanisa 327-fpsi11.web.unair.ac.id/artikel_detail-93076-UmumSejarah\%20Psikologi\%20Humanistik.html, diakses pada tanggal 16 November 2014 pukul 20.45 WIB.

Noor, Juliansyah, 2013, "Metodelogi Penelitian: Skripsi, Tesis, Desertasi, dan Karya Ilmiah", Cetakan ke-3, Kencana, Jakarta., 49, 128, 138, 152

Purnama, Sejati, 2012, "Hubungan Motivasi Kerja Dengan Prestasi Kerja Guru dan Karyawan di SMK Muhammadiyah 1 Sleman", Eprints UNY, http://eprints.uny.ac.id/9622/1/ JURNAL.pdf, diakses 11 Oktober 2014, pukul 23.10 WIB.

Rokhyadi, A., Haryono, T., \& Untoro, W. (2015). Impact of company's performance and green strategy on organizational culture: Phenomenon of Indonesia. International Journal of Research In Commerce \& Management, 6(11), 1-7.

Robbins, Stephen P. dan Timothy A. Judge, 2009, "Perilaku Organisasi (Organizational Behavior)", Edisi 12, Salemba Empat, Jakarta., 224

Robert, Thomas B., 1972, "Maslow's Human Motivation Needs Hierarchy: A Bibliography", De Kalb: Northern Illinois University, ERIC Document Reproduction Service No. 
ED069591, eric.ed.gov/?id=ED069591, diakses tanggal 5 November 2014 pukul 21.28 WIB.

Siagian, Sondang P., 2012, "Teori Motivasi dan Aplikasinya", Cetakan ke-4, PT. Rineka Cipta, Jakarta., 150-151

Sunyoto, Danang, 2010, "Uji Khi Kuadrat \& Regresi Untuk Penelitian", Edisi Pertama, Cetakan Pertama, Graha Ilmu, Yogyakarta., 97, 100-101, 108 , 2013, "Perilaku Organisasional: Teori, Kuesioner, dan Proses Analisis Data", Cetakan Pertama, CAPS (Center for Academic Publishing Service), Yogyakarta., 2-7, 10, 17, 148

Sutrisno, Edy, 2010, "Manajemen Sumber Daya Manusia", Edisi pertama, Cetakan ke-2, Kencana, Jakarta., 127-128

Wursanto, Ig., 2005, "Dasar-Dasar Ilmu Organisasi", Edisi 2, CV. Andi Offset, Yogyakarta., 299-300 